\title{
Integration of Forward Osmosis and Membrane Distillation for Sustainable Wastewater Reuse
}

\author{
Taqsim Husnain $^{\mathrm{a}^{*}}$, Yaolin Liu ${ }^{\mathrm{b}}$, Rumana Riffat ${ }^{\mathrm{a}}$, Baoxia Mi ${ }^{\mathrm{c}}$ \\ ${ }^{a}$ Department of Civil and Environmental Engineering, The George Washington University \\ $80122^{\text {nd }}$ Street NW, Washington, DC 20052, USA. \\ ${ }^{\mathrm{b}}$ College of Engineering, Architecture and Computer Sciences, Howard University \\ 2366 Sixth Street NW, Washington, DC 20059, USA. \\ c Department of Civil and Environmental Engineering, University of California, Berkeley \\ 623 Davis Hall, Berkeley, CA 94720, USA. E-mail: mib@berkeley.edu
}

\begin{abstract}
This study focuses on the performance of an integrated forward osmosis (FO) and membrane distillation (MD) process for wastewater reuse. FO worked as a pretreatment barrier to remove most contaminants in the feed water and MD was used to recover the draw solutes from FO effluent and simultaneously produce high-quality reusable water. A unique three-channel FOMD membrane module was designed and built to test water flux and contaminant removal in bench-scale experiments. It was found that the integrated FO-MD system possessed inherent flux balancing mechanism that enabled a stable and equal water flux for both FO and MD membranes for effective recovery of draw solution over long-term experiments. The FO-MD system was able to achieve more than 3 logs (> 99.9\%) removal of ammonium, COD, arsenic, and combined solutes in both synthetic and real wastewaters. Such a synergistic integration of FO and MD membrane processes offers three major advantages. First, the upstream FO process removes most contaminants and foulants from the feed solution, thus potentially diminishing the fouling and wetting problem for the downstream MD process. Second, the downstream MD process successfully recovers the draw solution for the FO process, enabling a constant water flux for FO. Third, the synergistic removal capability of FO and MD enabled the production of extremely high-quality product water. Additional benefits of the integrated process also include ambient pressure operation and potential use of renewable low-grade heat as the energy source.
\end{abstract}

\section{Keywords}

Forward osmosis; membrane distillation; wastewater reuse; ammonium; arsenic

\footnotetext{
* Corresponding author: Taqsim Husnain, Tel.: +1-571-484-3065; E-mail address: taqsim14@yahoo.com
} 


\section{Introduction}

It is predicted that $60 \%$ of world population will experience water scarcity by 2025 [1]. Therefore, a sustainable solution for clean, affordable water has become increasingly important. Membrane technology has been identified as one of the most effective approaches to address water scarcity problems. The most widely used membrane processes include microfiltration (MF), ultrafiltration (UF), nanofiltration (NF), and reverse osmosis (RO), which are pressuredriven and require external energy to pressurize the water through the membranes. Recently, new membrane processes, including osmotically driven forward osmosis (FO) and thermally driven membrane distillation (MD), have emerged and demonstrated many advantages over traditional pressure-driven membrane processes [2-4]. For example, FO and MD can operate under atmospheric pressure, be less susceptible to membrane fouling, and potentially use renewable low-grade energy source while attaining high water recovery and salt rejection [2-8].

Forward Osmosis is driven by natural osmotic pressure generated by concentrated draw solution to separate water from unwanted solutes using a semi-permeable membrane. FO is a process of dilution, which requires a further treatment step to recover the water from the diluted solution [9]. Therefore, it must be combined with a draw solution re-concentrating process to be used for desalination. Previous studies have compared FO with desalination processes and observed that it consumes 20-30\% less energy [10], generates less brine discharge to the environment [3], has low-fouling potential and high physical cleaning efficiency, thereby being friendly to the environment $[5,11,12]$. Despite successful use of FO as a part of seawater desalination [13], wastewater treatment/reuse [14], and liquid food processing [15], the problem that deters the widespread application of FO is the lack of suitable approach to re-concentrate the draw solution, so that it can constantly generate high osmotic pressure required for the FO process.

Such a difficulty associated with FO can be neatly circumvented by using MD to recover draw solutes from FO effluent and simultaneously produce high quality reusable water. MD combines membrane separation and evaporation processes: water vapor is transported through the pores of a hydrophobic micro-porous membrane via the temperature gradient-induced vapor pressure difference across the membrane [8]. Because the partial vapor pressure of water is only minimally affected by an increase in the concentration of dissolved salts, MD is an ideal process to re-concentrate FO draw solution, which contains relatively high salt concentration even after being diluted. Besides, water flux in $\mathrm{MD}$ is nearly constant for $\mathrm{NaCl}$ concentration ranging from 0.6 to $73 \mathrm{~g} / \mathrm{L}$ [2]. Similar to that in traditional thermal distillation processes, phase change in the MD process generates very pure product water by almost completely rejecting all non-volatile compounds. However, MD differs significantly from traditional distillation in that MD allows water/solute separation to occur well below the normal boiling point of water. MD is still considered as a relatively high energy consuming process; however it has the potential of using alternate sources of renewable energy for operation due to the low operating temperature $\left(40^{\circ} \mathrm{C}\right.$ or even lower). The MD process can be driven by low-degree temperature gradient using lowgrade heat (e.g., waste heat, geothermal heat, and solar heat) as energy input and can achieve high rejection of non-volatile water contaminants. The MD process has been recently used in water purification [16], desalination [17-23], cooling water treatment [24], concentration of RO 
retentate [2,25,26], recovery of valuable chemicals from industrial wastewater [27,28], concentration of juice or extracts [29-32] and alcohol-water separation [33,34].

One of the major challenges for MD process is membrane fouling and wetting, a severe problem that would diminish the durability of an MD membrane if it were used alone [35-37]. Wetting is mainly caused by the adsorption of hydrophilic substances onto the membrane surface, thereby gradually decreasing the membrane's hydrophobicity. Because hydrophobicity is key to prevent feed water from permeating through the MD membrane, reduction in hydrophobicity is detrimental to the rejection capacity of an MD membrane. When used as an integrated FO and MD system, FO may remove substances from the feed water that potentially cause fouling and wetting problems in the downstream MD process. Therefore, the presence of FO offers an excellent solution to MD membrane fouling.

The concept of combining FO and MD processes has been previously tested for wastewater reclamation [14]. In this study, FO membrane was laid directly on the top of an MD membrane to form a dual membrane; thus required a downstream unit (e.g., RO) to re-concentrate draw solution. The application of FO-MD hybrid process for sewer mining was investigated by incorporating granular activated carbon and UV oxidation to prevent contamination accumulation in draw solution [38]. The combined processes were applied for concentration of protein solution [39], dye wastewater treatment [40] and municipal wastewater side-stream treatment [41]. The effect of feed and draw solution temperatures of FO process on the rejection of trace organic contaminants were analyzed within a limited temperature variation of $20-40^{\circ} \mathrm{C}$ [42]. A pressure retarded osmosis - membrane distillation (PRO-MD) hybrid system demonstrated advantages of high water recovery rate and osmotic power generation [43]. However, research is still needed to systematically evaluate the performance of a integrated system. Additionally, efforts are needed to explore various combinations of FO and MD system and opportunities to optimize their configuration and performance. The present study presents a uniquely designed three-channel FO-MD module, which holds one FO and one MD membrane in parallel and three flow channels for feed solution, draw solution, and permeate water, respectively. The performance of the FO-MD system in the treatment and reuse of a domestic wastewater was systematically investigated. The effects of temperature and solute concentration on water flux of FO and MD membranes were also reported. The removal of ammonium, COD, arsenic, and combined solutes were studied using synthetic and real wastewater.

\section{Materials and Methods}

\subsection{FO and MD Membranes}

The FO membrane was provided by Hydration Technology Innovations (Albany, OR). The membrane has an asymmetric structure and is made of cellulose triacetate with an embedded polyester screen support. The total thickness of the membrane is approximately $50 \mu \mathrm{m}$ by examining the membrane cross-section using scanning electron microscopy. Based on the manufacturer's data, the maximum operating temperature for the $\mathrm{FO}$ membrane is $71^{\circ} \mathrm{C}$, the maximum trans-membrane pressure is $10 \mathrm{psi}$, and the operating $\mathrm{pH}$ range is 3 to 8 . The MD membrane was obtained from GE Osmonics (Minnetonka, MN). It is an asymmetric polypropylene membrane with a nominal pore size of $0.22 \mu \mathrm{m}$ and thickness of $130-170 \mu \mathrm{m}$. 


\subsection{Bench-Scale FO-MD System}

The schematic drawing of a bench-scale FO-MD membrane system is shown in Figure 1. Detail configuration and design the membrane module are presented in Figure 2. The system consists of a custom-built cross-flow membrane module with three channels for feed, draw and permeate, respectively. The three channels (each $77 \mathrm{~mm}$ long, $26 \mathrm{~mm}$ wide, $3 \mathrm{~mm}$ deep) are equally structured and separated by two parallel membrane coupons (one FO membrane and one MD membrane). Three variable speed gear pumps (Micropump, Vancouver, WA) were used to generate cross-flows that form closed loops for the feed, draw and permeate solutions, respectively. A constant cross-flow was maintained in each loop using a general purpose acrylic flow-meter (Cole-Parmer, Vernon Hills, IL). The draw and permeate solution tanks were each placed on a digital scale (Denver Instruments, Denver, CO) to enable the monitoring of weight changes by a computer to record FO and MD fluxes. Water baths (Neslab, Newington, NH) were used to regulate the temperatures of feed, draw and permeate solutions, respectively.

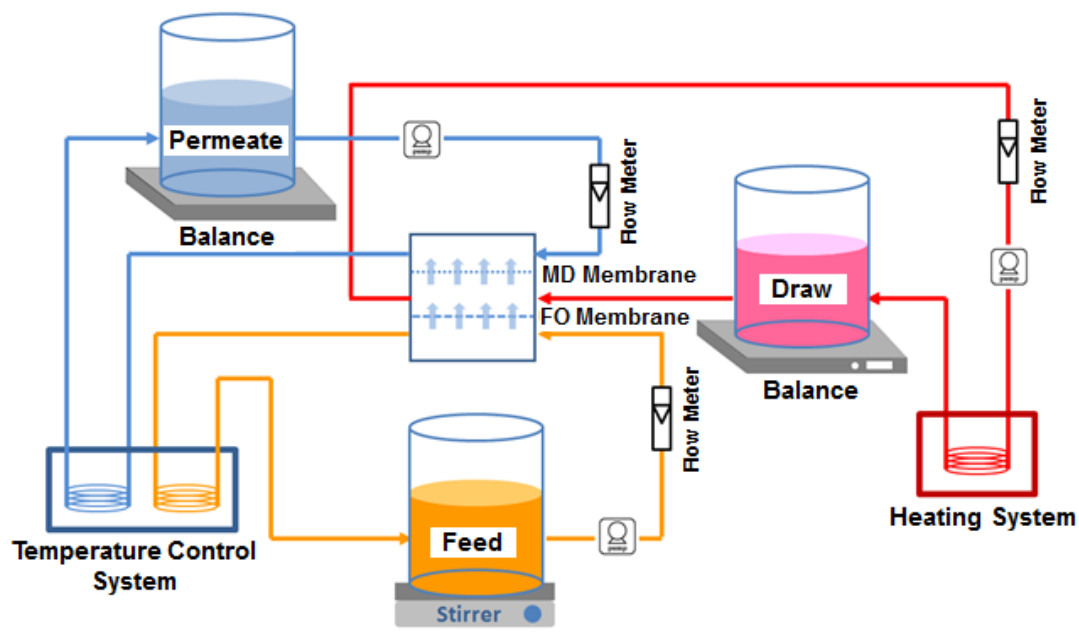

Figure 1. Schematic diagram of the FO-MD membrane system.

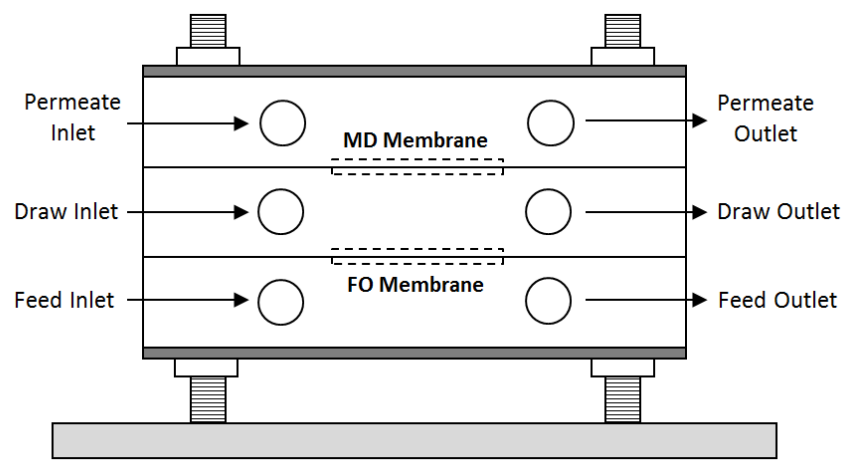

(a)

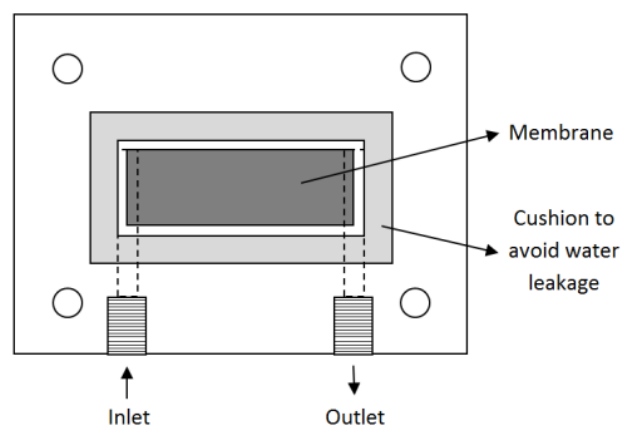

(b)

Figure 2. Elevation (a) and plan (b) of the FO-MD membrane module. 


\subsection{FO-MD Membrane Tests}

In order to test the FO and MD membrane flux, FO and MD membranes were placed in the three-channel membrane module. The feed, draw, and permeate tanks were filled with 2 L DI water, $2 \mathrm{~L} \mathrm{NaCl}$ solution $(0.25-2 \mathrm{M})$, and $2 \mathrm{~L}$ DI water, respectively. The FO membrane is placed between feed and draw solution channels, and the MD membrane between the draw and permeate channels. To start the flux experiment, the system was stabilized by circulating the solutions through the system for $30 \mathrm{~min}$ to reach a constant temperature for each solution. The temperature of the feed solution was always maintained at room temperature $\left(20 \pm 1{ }^{\circ} \mathrm{C}\right)$. The temperatures of draw and permeate solutions were varied between $40-70{ }^{\circ} \mathrm{C}$ and $15-30{ }^{\circ} \mathrm{C}$, respectively. The circulating flow rates for all three solutions were $0.4 \mathrm{~L} / \mathrm{min}$. The system was operated under atmospheric pressure.

The experimental protocol used in the contaminant removal experiments was similar as in the flux tests. However, instead of using DI water as feed, different feed solutions was used to test the removal of different types of contaminants. First, the removal of ammonium and COD, the two major components of wastewater, were tested by using 300-495 mg/L NH $4 \mathrm{Cl}$ solution and non-fat dry milk solution with a concentration in the range of 985-1800 mg/L COD as the feed solution. Then, synthetic wastewater (with composition shown in Table 1) and real wastewater secondary effluent (with water quality shown in Table 2) from Blue Plains Advanced Wastewater Treatment Plant (AWTP), Washington, D.C. was used to test the system performance in purifying typical wastewaters. Lastly, the removal of arsenic was tested by the FO-MD system using approximately $100-200 \mathrm{mg} / \mathrm{L} \mathrm{NaAsO}_{2}$ solution with $\mathrm{pH}$ adjusted to 7 (by adding $\mathrm{HCl}$ ) as the feed solution. In all the contaminant removal experiments, $1 \mathrm{M} \mathrm{NaCl}$ was used as the draw solution and DI water as permeate. The temperature of the feed, draw, and permeate solutions was maintained at $20^{\circ} \mathrm{C}, 50^{\circ} \mathrm{C}$, and $20^{\circ} \mathrm{C}$, respectively. The experiment was typically run for $48 \mathrm{~h}$ and then samples were collected from all three tanks to measure contaminant concentration in feed, draw, and permeate solutions.

Table 1. Composition of synthetic wastewaters.

\begin{tabular}{ccc}
\hline \hline Chemicals & Wastewater I & Wastewater II \\
\hline \hline $\mathrm{NaCl}$ & $2.0 \mathrm{mM}$ & $4.0 \mathrm{mM}$ \\
$\mathrm{KH}_{2} \mathrm{PO}_{4}$ & $0.4 \mathrm{mM}$ & $0.9 \mathrm{mM}$ \\
$\mathrm{NaHCO}_{3}$ & $0.5 \mathrm{mM}$ & $1.0 \mathrm{mM}$ \\
$\mathrm{CaCl}_{2}$ & $0.5 \mathrm{mM}$ & $1.0 \mathrm{mM}$ \\
$\mathrm{MgSO}_{4}$ & $0.6 \mathrm{mM}$ & $1.2 \mathrm{mM}$ \\
$\mathrm{NH}_{4} \mathrm{Cl}$ & $0.9 \mathrm{mM}$ & $1.9 \mathrm{mM}$ \\
\hline \hline
\end{tabular}


Table 2. Water quality of the Blue Plains AWTP secondary effluent.

\begin{tabular}{lccc}
\hline \hline Parameters & Units & Feed & Permeate \\
\hline \hline $\mathrm{pH}$ & - & $\sim 8.0$ & $6.9-7.3$ \\
Alkalinity & $\mathrm{mg} / \mathrm{L}$ as $\mathrm{CaCO}_{3}$ & 175 & 13.3 \\
Turbidity & $\mathrm{NTU}$ & $>150$ & 0.2 \\
Total Solids & $\mathrm{mg} / \mathrm{L}$ & 24.6 & 0 \\
Total COD & $\mathrm{mg} / \mathrm{L}$ & 46.2 & 0 \\
Conductivity & $\mu \mathrm{S} / \mathrm{cm}$ & 1685 & $<10$ \\
\hline \hline
\end{tabular}

\subsection{Synthetic Wastewater, $\mathrm{NH}_{4}^{+}$, and $\mathrm{COD}$ Analysis}

An Accumet Excel XL25 ISE meter (Fisher Scientific, Pittsburgh, PA) with a combination ion selective electrode was used to measure ammonium $\left(\mathrm{NH}_{4}{ }^{+}\right)$concentration in solutions. The standard method 5220 D, Closed Reflux, Colorimetric Method, was used for COD measurement [44]. The concentration of combined solutes in synthetic wastewaters was monitored by conductivity measurement, which is a fast, inexpensive, and reliable way of determining the ionic contents of a solution [45]. In the present study, the conductivity of the feed, draw, and permeate solutions was constantly monitored using Accumet Excel XL30 Conductivity meter (Fisher Scientific, Pittsburgh, PA) to evaluate the overall solute transport in the FO-MD process. Serial dilutions were made to the more concentrated feed and draw solutions to make sure all conductivity readings are within a linear correlation range.

\subsection{Arsenic Analysis}

The ascorbic acid method for phosphorus analysis was modified to determine arsenite, As(III) concentration in aqueous solution [46]. Potassium iodate was used to convert arsenite to arsenate, $\mathrm{As}(\mathrm{V})$. Arsenate then reacted with ammonium molybdate and potassium antimonyl tartrate in the acid media to form molybdoarsenate, which subsequently reacted with ascorbic acid to form intense blue color. A similar procedure was also used for $\mathrm{As}(\mathrm{V})$ measurement without the addition of potassium iodate.

The detailed analytical procedure is described as follows. First, hydrochloric acid (1M) and potassium iodate $\left(\mathrm{KIO}_{3}\right)(0.1 \mathrm{M})$ stock solutions were prepared for adjusting sample acidity and oxidizing arsenite to arsenate. Stock solution of sulfuric acid $(5 \mathrm{~N})$, potassium antimonyl tartrate $\left(\mathrm{K}(\mathrm{SbO}) \mathrm{C}_{4} \mathrm{H}_{4} \mathrm{O}_{6} .1 / 2 \mathrm{H}_{2} \mathrm{O}\right)(2.66 \mathrm{~g} / \mathrm{L})$, ammonium molybdate $\left(\left(\mathrm{NH}_{4}\right)_{6} \mathrm{Mo}_{7} \mathrm{O}_{24} .4 \mathrm{H}_{2} \mathrm{O}\right)(40 \mathrm{~g} / \mathrm{L})$, and ascorbic acid $\left(\mathrm{C}_{6} \mathrm{H}_{8} \mathrm{O}_{6}\right)(0.1 \mathrm{M})$ were also prepared. Then $100 \mathrm{~mL}$ combined reagent was prepared by mixing $50 \mathrm{~mL}$ sulfuric acid, $5 \mathrm{~mL}$ potassium antimonyl tartrate, $15 \mathrm{~mL}$ ammonium molybdate, and $30 \mathrm{~mL}$ ascorbic acid stock solutions. The combined reagent was used to react with arsenate for color formation and found to be stable for $4 \mathrm{~h}$. To start arsenic analysis, each sample was diluted as needed to contain $0.4-4 \mathrm{mg} / \mathrm{L}$ arsenic, followed by adding $0.3 \mathrm{~mL}$ hydrochloric acid (1M) to $10 \mathrm{~mL}$ sample to adjust the acidity of the solution to about $0.024 \mathrm{M}$. Then, $0.05 \mathrm{~mL}$ potassium iodate solution $(0.1 \mathrm{M})$ was added and oxidation was allowed to 
proceed for $1 \mathrm{~h}$. Next, $2 \mathrm{~mL}$ combined reagent and $2.15 \mathrm{~mL}$ DI water were added for color formation. The sample absorbance was measured at $880 \mathrm{~nm}$ using a DR3800 spectrophotometer (HACH, Loveland, CO). A standard curve prepared using standard solutions containing 0.2, 1, 2, 3 , and $3.75 \mathrm{mg} / \mathrm{L}$ sodium arsenite $\left(\mathrm{NaAsO}_{2}\right)$ was used to convert absorbance reading to arsenic concentration.

\section{Results and Discussion}

\subsection{Flux Characterization}

\subsubsection{FO Membrane Flux}

Since the draw solution for the FO process serves as the feed for the MD process in the integrated FO-MD system, the draw solution is required to provide high osmotic pressure to FO and elevated vapor pressure (i.e., high temperature) to MD. Therefore, the effects of draw solution concentration and temperature on the FO membrane flux were studied in the integrated system. The draw solution concentration was varied from $0.25 \mathrm{M}$ to $2.0 \mathrm{M}$ of $\mathrm{NaCl}$. For real world application, FO has the potential of being a part of ship-board wastewater treatment, where seawater (approx. $0.5 \mathrm{M} \mathrm{NaCl}$ concentration) can be directly used as draw solution. Figure 3(a) shows the FO membrane flux obtained at various draw solution concentrations. As expected, FO membrane flux increases with increasing draw solution concentration because higher concentration generates higher osmotic driving force. In addition, the effect of temperature on FO membrane flux was tested by using a fixed draw solution concentration of $1 \mathrm{M} \mathrm{NaCl}$ while varying draw solution temperature between $40-70{ }^{\circ} \mathrm{C}$. Figure $3(\mathrm{~b})$ shows that increasing draw solution temperature also enhances FO membrane flux. This is because the faster solute transport at higher temperature reduces concentration polarization effects and thereby results in higher flux. Here, the experiments were conducted in duplicates, and the presented data points are the average values of the experiments.

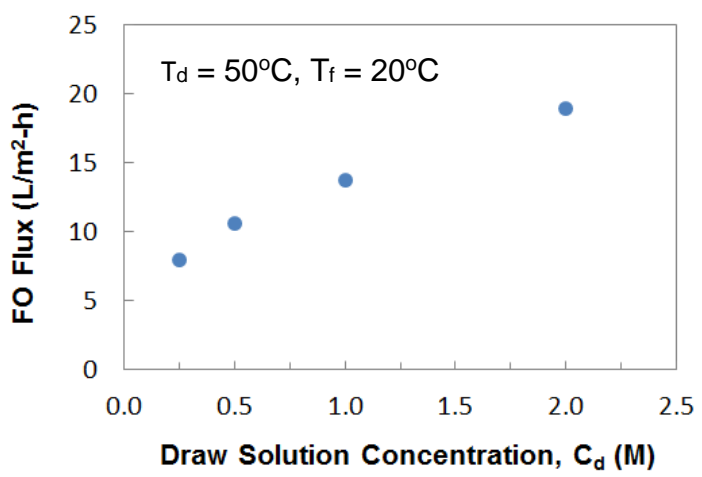

(a)

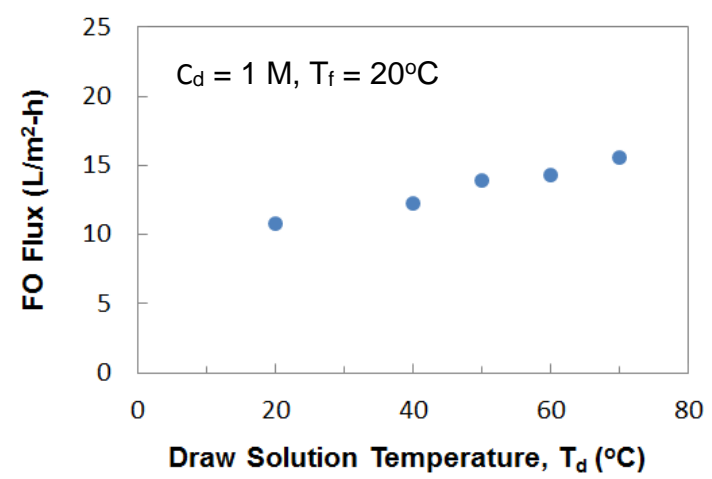

(b)

Figure 3. Effects of draw solution concentration (a) and temperature (b) on FO membrane flux. $T_{d}$ and $T_{f}$ represent the temperature of draw and feed solution, respectively. $C_{d}$ represents the $\mathrm{NaCl}$ concentration of the draw solution. 


\subsubsection{Membrane Flux}

The effects of draw solution concentration and temperature on the MD membrane flux were investigated in the FO-MD system. Figure 4(a) shows that draw solution concentration only slightly affects MD flux, which is expected because the solution concentration has little effects on the vapor pressure of a solution [2]. The draw solution temperature instead is the predominant factor controlling MD membrane flux. As shown in Figure 4(b), the MD membrane flux increases drastically with increasing draw solution temperature. In addition, the effect of permeate temperature on the MD membrane flux was also studied. The MD flux increases only slightly with decreasing permeate temperature when the draw solution temperature remains constant, as presented in Figure 4(b). The different effects of draw and permeate solution temperature indicate that with the same temperature gradient, the higher the average temperature, the higher is the MD flux. For example, an FO-MD system with draw and permeate solution temperature of $50^{\circ} \mathrm{C}$ and $30^{\circ} \mathrm{C}$ will perform better in terms of MD flux than a system with $40^{\circ} \mathrm{C}$ and $20^{\circ} \mathrm{C}$, even though they both have the same $20^{\circ} \mathrm{C}$ temperature gradient. Overall, it is important to understand that the MD membrane flux is more dependent on the draw solution temperature compared to permeate solution temperature.

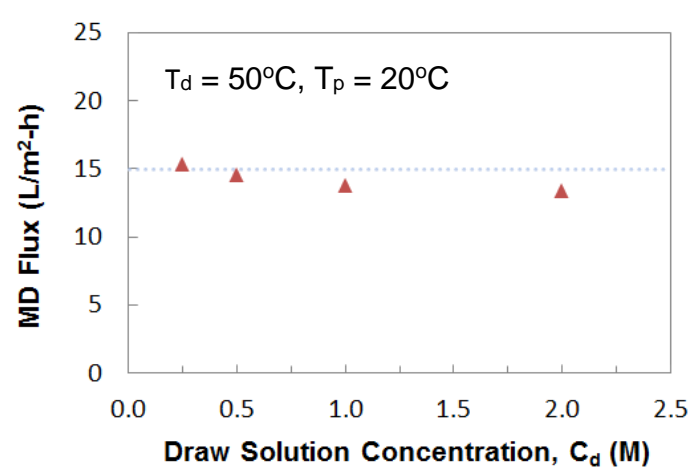

(a)

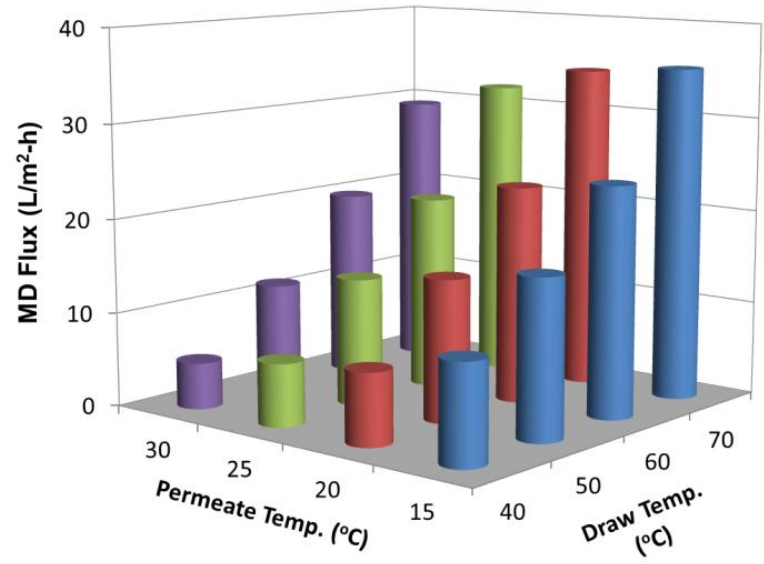

(b)

Figure 4. Effects of concentration (a) and temperature (b) on MD membrane flux. $\mathrm{T}_{\mathrm{d}}$ and $\mathrm{T}_{\mathrm{p}}$ represent the temperature of draw and permeate solution, respectively.

\subsubsection{Balanced FO and MD Flux}

One advantage of the FO-MD system is the inherent flux balancing mechanism during operation. This is beneficial for effective recovery of draw solution over long-term FO experiments. If the FO membrane flux is higher than the MD membrane flux when the system was started, the draw solution concentration would get diluted over time and eventually reduces the FO flux to the same as the MD flux. Vice versa, if the FO membrane flux is lower than the MD membrane flux at the beginning, the draw solution would get concentrated and result in an increase in FO flux. 
Therefore, at steady state of the FO-MD system operation, the draw solution is diluted by the FO process and concentrated by the MD process at the same rate, thus the concentration of draw solution and the FO and MD fluxes remain constant with time. Figure 5 demonstrated such a steady state operation of the FO-MD system where DI water, $1 \mathrm{M} \mathrm{NaCl}$ solution, and DI were used as feed, draw, and permeate solutions, respectively. The temperature of the feed, draw and permeate solutions were maintained at $20^{\circ} \mathrm{C}, 50{ }^{\circ} \mathrm{C}$ and $20^{\circ} \mathrm{C}$, respectively. During the $1200 \mathrm{~min}$ operation, both the FO membrane flux in Figure 5(a) and MD membrane flux in Figure 5(b) remains constant at around $14.4 \mathrm{~L} / \mathrm{m}^{2} . \mathrm{h}$. Additionally, as shown in Table 3, the initial and final conductivity of the draw solution in different experiments remain the same, demonstrating the successful recovery of draw solution by the MD system that results in a constant draw solution concentration. Therefore, such a natural flux balancing or draw solution recovery mechanism allows for a stable operation of the FO-MD system over a long time period.

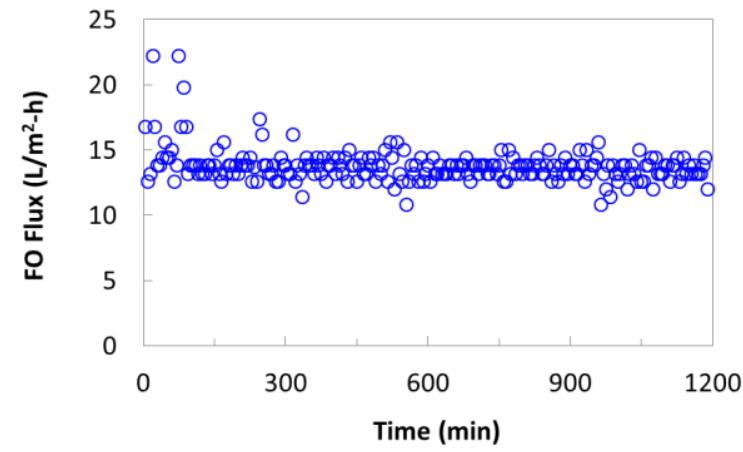

(a)

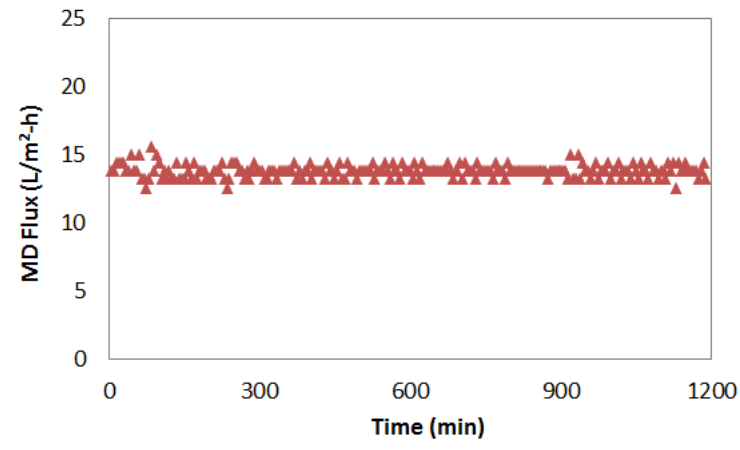

(b)

Figure 5. Balanced FO (a) and MD (b) fluxes in steady state.

Table 3. Initial and final conductivity measurements of draw solutions.

\begin{tabular}{c|c|c|c}
\hline \hline \multirow{2}{*}{$\begin{array}{c}\text { Feed } \\
\text { Solutions }\end{array}$} & $\begin{array}{c}\text { Draw } \\
\text { Solutions }\end{array}$ & \multicolumn{2}{c}{$\begin{array}{c}\text { Conductivity (mS/cm) } \\
\text { Initial }\end{array}$} \\
\hline \hline DI Water & $2.0 \mathrm{M} \mathrm{NaCl}$ & 147.4 & 147.2 \\
Ammonium & $1.0 \mathrm{M} \mathrm{NaCl}$ & 84.2 & 81.4 \\
Wastewater I & $0.5 \mathrm{M} \mathrm{NaCl}$ & 47.0 & 42.6 \\
\hline
\end{tabular}

\subsection{Removal of Contaminants}

A thorough study was carried out to evaluate the contaminant removal efficiency of the integrated FO-MD process. Conductivities of the feed, draw and permeate solutions were constantly monitored to identify the overall solute transport in the FO-MD process. Some solutes, though of very small quantity, still permeate through the FO membrane. These solutes were removed, however, by the downstream MD process. Therefore, the total efficiency of the integrated process in removing various contaminants was extremely high. 


\subsection{1 $\mathrm{NH}_{4}{ }^{+}$and COD Removal}

Excess nitrogen in wastewater effluent can cause eutrophication and damage the receiving water bodies. The current regulation by the Environmental Protection Agency (EPA, US) limits the discharge of nitrogen to $3-4 \mathrm{mg} / \mathrm{L}$, which is difficult to maintain by the conventional biological wastewater treatment processes, especially in winter. During a secondary wastewater treatment process, organic-nitrogen in the raw sewage (typically from organic wastes, fecal materials, and urea) is converted to ammonium through hydrolysis. Therefore, in the context of wastewater reuse, ammonium removal was tested by the FO-MD membrane system using feed solutions containing various concentrations of $\mathrm{NH}_{4} \mathrm{Cl}$. The ammonium concentration in the feed, draw and permeate solutions were measured before and after 48 hours of experiments. The feed solution for ammonium and COD test contains 300-495 mg/L NH $4 \mathrm{Cl}$ and $985-1800 \mathrm{mg} / \mathrm{L}$ non-fat dry milk, respectively. $1 \mathrm{M} \mathrm{NaCl}$ solution and DI water were used as draw and permeate solutions, respectively. The temperature of the feed, draw and permeate solutions were maintained at $20^{\circ} \mathrm{C}$, $50{ }^{\circ} \mathrm{C}$, and $20^{\circ} \mathrm{C}$, respectively. Detection limits of the ammonium and COD analysis are 0.1 $\mathrm{mg} / \mathrm{L}$ and $0.7 \mathrm{mg} / \mathrm{L}$, respectively. As shown in Figure 6, for the tested feed solutions with ammonium concentration ranged in $300-495 \mathrm{mg} / \mathrm{L}$, no or very little ammonium $(\sim 0.18 \mathrm{mg} / \mathrm{L})$ was detected in the permeate solution, indicating almost $100 \%$ rejection.

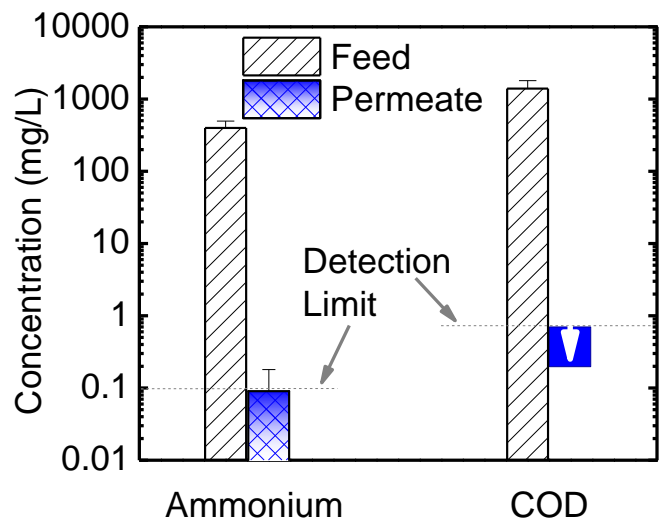

Figure 6. Ammonium and COD removal by the FO-MD system.

Since COD is another major component in wastewater, the COD removal efficiency was tested by the FO-MD membrane system. A typical domestic wastewater contains $250-1000$ $\mathrm{mg} / \mathrm{L}$ of COD [47]. Non-fat dry milk was used in the COD removal tests, because the commercially available non-fat dry milk composition is very similar to the COD composition in a secondary effluent. Figure 6 shows that the FO-MD system achieved complete removal of COD. Additionally, the COD concentration in the draw solution was measured and found that FO membrane alone can achieve around 90\% rejection of COD after 48 hours of accumulated solute transport. A mass balance of feed, draw and permeate streams for the initial feed COD of $985 \mathrm{mg} / \mathrm{L}$ demonstrated that final COD concentration of the feed increased to $5043 \mathrm{mg} / \mathrm{L}$, indicating that the upstream FO pretreatment process help remove organic substances from the feed water, thus greatly preventing fouling of the downstream MD membrane. Therefore, the integration of FO and MD membrane processes not only results in high contaminant removal, 
but also provides an effective strategy to solve the fouling and wetting problems for MD membrane processes.

\subsubsection{Removal of Combined Solutes in Wastewater}

In order to test the overall removal of combined solutes in wastewater by the FO-MD system, both synthetic wastewater and real wastewater secondary effluent were used. The chemical compositions of the synthetic wastewaters are listed in Table 1 . The conductivity of feed and permeate solutions were measured to quantify solute removal. Figure 7 shows the solute removal by the FO-MD system using synthetic wastewater (Wastewater II in Table 1) and real wastewater secondary effluent as the feed. $1 \mathrm{M} \mathrm{NaCl}$ solution and DI water were used as draw and permeate solutions, respectively. The temperature of the feed, draw and permeate solutions were maintained at $20{ }^{\circ} \mathrm{C}, 50{ }^{\circ} \mathrm{C}$ and $20{ }^{\circ} \mathrm{C}$, respectively. As shown in Figure 7 , the final conductivity of the permeate solution remains comparable to that of DI water, indicating no passage of solutes across the MD membrane. Overall, the FO-MD system demonstrated a 3-log (or higher than $99.9 \%$ ) rejection of the combined chemical solutes in wastewater.

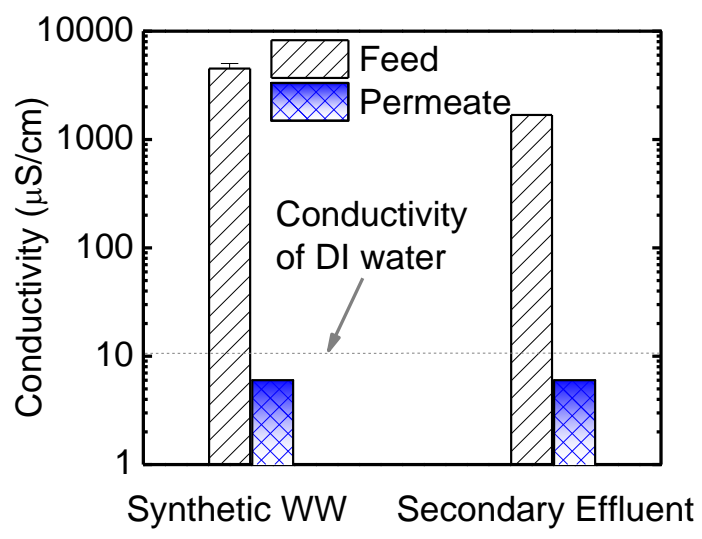

Figure 7. Solute removal by the FO-MD system using synthetic and real wastewater.

To further study the performance of the FO-MD system for wastewater reuse, secondary effluent from Blue Plains Advanced Wastewater Treatment Plant, Washington D.C. was used as the feed solution. A variety of water quality parameters of the wastewater were tested before and after FO-MD treatment. As shown in Table 2, both the alkalinity and turbidity of the wastewater were significantly lowered by the FO-MD treatment. The turbidity of the secondary effluent was more than $150 \mathrm{NTU}$, while after passing through the FO-MD system, the permeate turbidity was below 0.2 NTU, which meets the EPA standard for municipal drinking water. Additionally, the integrated FO-MD system was also able to achieve a high degree removal of color. The secondary effluents obtained from Blue Plains showed some reddish color due to the use of $\mathrm{FeCl}_{3}$ during the treatment process, but no color was observed in either the draw or permeate tank. The FO-MD treatment also balanced the $\mathrm{pH}$ of the permeate water to around 6.9-7.3 for all the experiments no matter how the feed solution $\mathrm{pH}$ varied. Finally, the combined solute removal by the FO-MD system was monitored by conductivity measurements, and the results are shown 
in Figure 7. Again, the conductivity of the product water reached DI water quality after the FOMD system treatment, demonstrating a close to 3-log removal of combined solutes.

\subsubsection{Removal of As(III) and As(V) by the FO-MD System}

Arsenic as a contaminant was selected to test with the FO-MD system for two reasons. First of all, arsenic is a contaminant present in natural waters that causes numerous health effects in many regions of the world. Second, the efficiency of arsenic removal by membrane processes like nanofiltration (NF) and reverse osmosis (RO) is often low, especially for As(III) species [46,48]. For example, previous studies reported an As(III) removal efficiency of only $20-30 \%$ by $\mathrm{NF}$ and $50-85 \%$ by $\mathrm{RO}$ [49]. This is because in the typical $\mathrm{pH}$ range of natural waters, As(III) is mainly present as neutral species $\left(\mathrm{H}_{3} \mathrm{AsO}_{3}\right)$ and it is widely known that the removal efficiency of small neutral species by NF/RO membranes is typically much lower than that of charged ions. Therefore, arsenic was used as a challenging contaminant to test the performance of the FO-MD system in removing small neutral species.

The measured concentrations of $\mathrm{As}(\mathrm{III})$ and $\mathrm{As}(\mathrm{V})$ in the feed, draw, and permeate solutions are shown in Table 4. The feed solution contains 100-200 mg/L NaAsO $2.1 \mathrm{M} \mathrm{NaCl}$ solution and DI water were used as draw and permeate solutions, respectively. The temperature of the feed, draw and permeate solutions were maintained at $20{ }^{\circ} \mathrm{C}, 50{ }^{\circ} \mathrm{C}$ and $20{ }^{\circ} \mathrm{C}$, respectively. The arsenic removal efficiency (Figure 8) by the FO membrane alone was calculated based on arsenic concentrations in feed and draw solutions, while the removal by the integrated FO-MD process was calculated based on the arsenic concentrations in feed and permeate solutions. As shown in Table 4, a significant amount of As(III) was observed in the draw solution after 48-hour testing, indicating low rejection of $\mathrm{As}$ (III) by the FO membrane. As demonstrated in Figure 8, the removal efficiency of neutral As(III) by the FO membrane was $83-90 \%$, while that of As(V) was much higher, reaching around $99.4 \%$. This is consistent with the literature because the solute transport in the FO membrane is similar to that in NF/RO membranes, thus low removal efficiency for neutral species is expected.

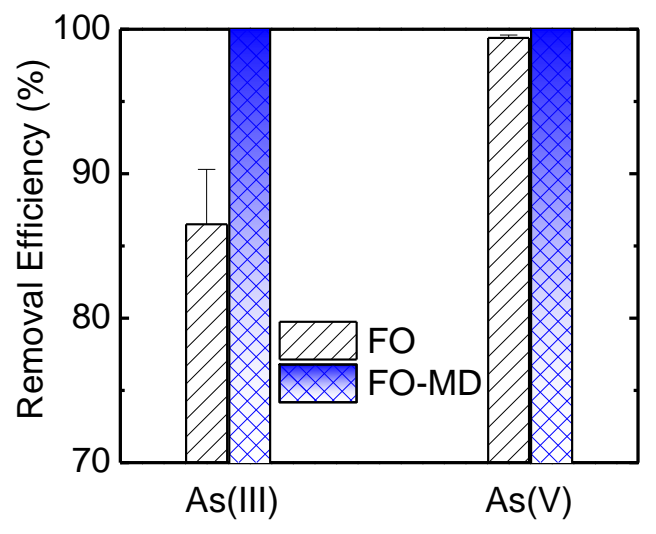

Figure 8. Arsenic removal by the FO-MD membrane system. 
Table 4. As(III) and As(V) concentration (mg/L) in feed and draw solutions.

\begin{tabular}{l|cc|cc|cc}
\hline \hline & \multicolumn{2}{|c|}{ Feed } & \multicolumn{2}{c|}{ Draw } & \multicolumn{2}{c}{ Permeate } \\
& $\mathbf{A s}(\mathbf{I I I})$ & $\mathbf{A s}(\mathbf{V})$ & $\mathbf{A s}(\mathbf{I I I})$ & $\mathbf{A s}(\mathbf{V})$ & $\mathbf{A s}(\mathbf{I I I})$ & $\mathbf{A s}(\mathbf{V})$ \\
\hline \hline Sample I & 80.1 & 60.2 & 13.8 & 0.2 & $<0.2$ & $<0.2$ \\
Sample II & 202.3 & 39.4 & 19.6 & 0.3 & $<0.2$ & $<0.2$ \\
\hline \hline
\end{tabular}

Even though the FO membrane alone is not very efficient in removing As(III), the integrated FO-MD system was able to achieve very high rejection of both As(III) and As(V). As shown in Table 4, both As(III) and As(V) concentration in the permeate is below the detection limit of 0.2 $\mathrm{mg} / \mathrm{L}$, demonstrating an almost 3-log or $99.9 \%$ removal. Note that due to the limit of the arsenic analysis method, a relative high concentration of arsenic in the feed solution was used in order to demonstrate the high removal efficiency. In the future, analytical instrument with much lower detection limit will be used to determine rejection efficiency under more realistic arsenic concentrations.

\section{Conclusions}

This study presents an integrated FO-MD membrane system for sustainable reuse of wastewater. The FO-MD system was able to achieve very high performance in terms of water flux and contaminant removal. The inherent flux balancing mechanism during FO-MD operation enabled a stable and equal water flux for both FO and MD membranes over long-term experiments. The FO-MD system was able to achieve more than $3 \operatorname{logs}(>99.9 \%)$ removal of ammonium, COD, arsenic, and combined solutes in both synthetic and real wastewaters. Such a synergistic integration of FO and MD membrane processes offers three major advantages. First, the upstream FO process removes most of the contaminants from the feed solution, thus potentially diminishing the fouling and wetting problem for the downstream MD process. Second, the downstream MD process successfully recovers the draw solution for the FO process, enabling a constant water flux for FO. Third, the synergistic removal capability of FO and MD enabled the production of an extremely high-quality product water. For all the feed water tested, the product water quality was comparable to DI water due to the dual barrier created by FO and MD membranes. Additional benefits of the integrated process also include ambient pressure operation and potential use of renewable low-grade heat as the energy source.

\section{Acknowledgements}

The authors gratefully acknowledged the supports by the USAID Phase 4 of the Pakistan-US Science and Technology Cooperation Program and National Science Foundation under Grant no. CBET-1158601. The opinions expressed herein are those of the authors and do not necessarily reflect those of the sponsors. The authors would like to thank the Blue Plains Advanced Wastewater Treatment Plant, Washington, D.C. for providing the wastewater samples and Dr. Ed Beaudry of Hydration Technology Innovations for providing the FO membrane. 


\section{References}

[1] El-Dessouky, H.T. and Ettouney, H.M. (2002) Fundamentals of Salt Water Desalination, Elsevier Science, Amsterdam, 2002.

[2] Martinetti, C., Childress, A. and Cath, T. (2009) High Recovery of Concentrated RO Brines using Forward Osmosis and Membrane Distillation. Journal of Membrane Science, 331, 31-39. http://dx.doi.org/10.1016/j.memsci.2009.01.003

[3] Cath, T., Childress, A. and Elimelech, M. (2006) Forward Osmosis: Principles, Applications, and Recent Developments. Journal of Membrane Science, 281, 70-87. http://dx.doi.org/10.1016/j.memsci.2006.05.048

[4] Chen, T.C., Ho, C.D. and Yeh, H.M. (2009) Theoretical Modeling and Experimental Analysis of Direct Contact Membrane Distillation. Journal of Membrane Science, 330, 279-287. http://dx.doi.org/10.1016/j.memsci.2008.12.063

[5] Mi, B. and Elimelech, M. (2010) Organic Fouling of Forward Osmosis Membranes: Fouling Reversibility and Cleaning without Chemical Reagents. Journal of Membrane Science, 348, 337-345. http://dx.doi.org/10.1016/j.memsci.2009.11.021

[6] Achilli, A., Cath, T., Marchand, E. and Childress, A. (2009) The Forward Osmosis Membrane Bioreactor: A Low Fouling Alternative to MBR Processes. Desalination, 239, 10-21. http://dx.doi.org/10.1016/j.desal.2008.02.022

[7] Cornelissen, E., Harmsen, D., de Korte, K., Ruiken, C., Qin, J., Oo, H. and Wessels, L. (2008) Membrane Fouling and Process Performance of Forward Osmosis Membranes on Activated Sludge. Journal of Membrane Science, 319, 158-168. http://dx.doi.org/10.1016/j.memsci.2008.03.048

[8] Burgoyne, A. and Vahdati, M.M. (2000) Direct Contact Membrane Distillation. Separation Science and Technology, 35, 1257-1284. http://dx.doi.org/10.1081/SS-100100224

[9] Van der Bruggen, B. and Luis, P. (2015) Forward osmosis: understanding the hype. Rev. Chem. Eng., 31(1), 1-12. http://dx.doi.org/10.1515/revce-2014-0033

[10] McGinnis, R.L. and Elimelech, M. (2007) Energy Requirements of Ammonia-Carbon Dioxide Forward Osmosis Desalination. Desalination, 207, 370-382. http://dx.doi.org/10.1016/j.desal.2006.08.012

[11] Mi, B. and Elimelech, M. (2010) Gypsum Scaling and Cleaning in Forward Osmosis: Measurement and Mechanisms. Environmental Science and Technology, 44, 2022-2028. http://dx.doi.org/10.1021/es903623r

[12] Husnain, T., Mi, B.X. and Riffat, R. (2015) Fouling and Long-term Durability of an Integrated Forward Osmosis and Membrane Distillation System. Water Science and Technology. In Press, Available Online 10 August 2015. http://dx.doi.org/10.2166/wst.2015.415

[13] Kravath, R.E. and Davis, J.A. (1975) Desalination of Seawater by Direct Osmosis. Desalination, 16, 151-155. http://dx.doi.org/10.1016/S0011-9164(00)82089-5

[14] Cath, T.Y., Adams, D. and Childress, A.E. (2005) Membrane Contactor Processes for Wastewater Reclamation in Space II. Combined Direct Osmosis, Osmotic Distillation, and Membrane Distillation for Treatment of Metabolic Wastewater. Journal of Membrane Science, 257, 111-119. http://dx.doi.org/10.1016/j.memsci.2004.07.039

[15] Jiao, B., Cassano, A. and Drioli, E. (2004) Recent Advances on Membrane Processes for the Concentration of Fruit Juices: A Review. Journal of Food Engineering, 63, 303-324. http://dx.doi.org/10.1016/j.jfoodeng.2003.08.003

[16] Qu, D., Wang, J., Hou, D.Y., Luan, Z.K., Fan, B. and Zhao, C.W. (2009) Experimental Study of Arsenic Removal by Direct Contact Membrane Distillation. Journal of Hazardous Materials, 163, 874-879. http://dx.doi.org/10.1016/j.jhazmat.2008.07.042

[17] Wijekoon, K., Hai, F. Ibney., Kang, J., Price, W. E., Cath, T. and Nghiem, L. D. (2014) Rejection and Fate of Trace Organic Compounds (TrOCs) during Membrane Distillation. Journal of Membrane Science, 453, 636642. http://dx.doi.org/10.1016/j.memsci.2013.12.002 
[18] Alklaibi, A.M. (2008) The Potential of Membrane Distillation as a Stand-alone Desalination process. Desalination, 223, 375-385. http://dx.doi.org/10.1016/j.desal.2007.01.201

[19] Mericq, J.P., Laborie, S. and Cabassud, C. (2009) Vacuum Membrane Distillation for an Integrated Seawater Desalination Process. Desalination and Water Treatment, 9, 287-296. http://dx.doi.org/10.5004/dwt.2009.862

[20] Wang, K.Y., Foo, S.W. and Chung, T.S. (2009) Mixed Matrix PVDF Hollow Fiber Membranes with Nanoscale Pores for Desalination through Direct Contact Membrane Distillation. Industrial and Engineering Chemistry Research, 48, 4474-4483. http://dx.doi.org/10.1021/ie8009704

[21] Galvez, J.B., Garcia-Rodriguez, L. and Martin-Mateos, I. (2009) Seawater Desalination by an Innovative Solar-powered Membrane Distillation System: The MEDESOL Project. Desalination, 246, 567-576. http://dx.doi.org/10.1016/j.desal.2008.12.005

[22] Cerneaux, S., Struzynska, I., Kujawski, W.M., Persin, M. and Larbot, A. (2009) Comparison of Various Membrane Distillation Methods for Desalination sing hydrophobic Ceramic Membranes. Journal of Membrane Science, 337, 55-60. http://dx.doi.org/10.1016/j.memsci.2009.03.025

[23] Song, L.M., Ma, L.M., Liao, X.H., Kosaraju, P.B., Irish, J.R. and Sirkar, K.K. (2008) Pilot Plant Studies of Novel Membranes and Devices For Direct Contact Membrane Distillation-Based Desalination. Journal of Membrane Science, 323, 257-270. http://dx.doi.org/10.1016/j.memsci.2008.05.079

[24] Wang, J., Qu, D., Tie, M., Ren, H.J., Peng, X.J. and Luan, Z.K. (2008) Effect of Coagulation Pretreatment on Membrane Distillation Process for Desalination of Recirculating Cooling Water. Separation and Purification Technology, 64, 108-115. http://dx.doi.org/10.1016/j.seppur.2008.07.022

[25] Qu, D. Wang, J., Fan, B., Luan, Z.K. and Hou, D.Y.(2009) Study on Concentrating Primary Reverse Osmosis Retentate by Direct Contact Membrane Distillation. Desalination, 247, 540-550. http://dx.doi.org/10.1016/j.desal.2008.08.004

[26] Hou, D.Y., Wang, J., Qu, D., Luan, Z.K., Zhao, C.W. and Ren, X.J. (2009) Preparation of Hydrophobic PVDF Hollow Fiber Membranes for Desalination through Membrane Distillation. Water Science and Technology, 59, 1219-1226. http://dx.doi.org/10.2166/wst.2009.080

[27] El-Abbassi, A., Hafidi, A., Garcia-Payo, M.C. and Khayet, M. (2009) Concentration of Olive Mill Wastewater by Membrane Distillation for Polyphenols Recovery. Desalination, 245, 670-674. http://dx.doi.org/10.1016/j.desal.2009.02.035

[28] Soni, V., Abildskov, J., Jonsson, G. and Gani, R. (2008) Modeling and Analysis of Vacuum Membrane Distillation for the Recovery of Volatile Aroma Compounds from Black Currant Juice. Journal of Membrane Science, 320, 442-455. http://dx.doi.org/10.1016/j.memsci.2008.04.025

[29] Belafi-Bako, K. and Koroknai, B. (2006) Enhanced Water Flux in Fruit Juice Concentration: Coupled Operation of Osmotic Evaporation snd Membrane Distillation. Journal of Membrane Science, 269, 187-193. http://dx.doi.org/10.1016/j.memsci.2005.06.034

[30] Gunka, S., Verbych, S., Bryk, M. and Hilal, N. (2006) Concentration of Apple Juice using Direct Contact Membrane Distillation. Desalination, 190, 117-124. http://dx.doi.org/10.1016/j.desal.2005.09.001

[31] Kozak, A., Bekassy-Molnar, E. and Vatai, G. (2009) Production of Black-Currant Juice Concentrate by using Membrane Distillation. Desalination, 241, 309-314. http://dx.doi.org/10.1016/j.desal.2008.02.033

[32] Zhao, Z.P., Ma, F.W., Liu, W.F. and Liu, D.Z. (2008) Concentration of Ginseng Extracts Aqueous Solution by Vacuum Membrane Distillation, Effects of operating conditions. Desalination, 234, 152-157. http://dx.doi.org/10.1016/j.desal.2007.09.081

[33] Vane, L.M. and Alvarez, F.R. (2008) Membrane-Assisted Vapor Stripping: Energy Efficient Hybrid Distillation-Vapor Permeation Process for Alcohol-Water Separation. Journal of Chemical Technology and Biotechnology, 83, 1275-1287. http://dx.doi.org/10.1002/jctb.1941

[34] Tomaszewska, M and Mientka, A. (2009) Separation of $\mathrm{HCl}$ from HCl-H2SO4 Solutions by Membrane Distillation. Desalination, 240, 244-250. http://dx.doi.org/10.1016/j.desal.2007.10.093 
[35] Srisurichan, S., Jiraratananon, R. and Fane, A.G. (2005) Humic Acid Fouling in the Membrane Distillation Process. Desalination, 174, 63-72. http://dx.doi.org/10.1016/j.desal.2004.09.003

[36] Gryta, M., Tomaszewska, M. and Karakulski, K. (2006) Wastewater Treatment by Membrane Distillation. Desalination, 198, 67-73. http://dx.doi.org/10.1016/j.desal.2006.09.010

[37] Gryta, M. (2008) Fouling in Direct Contact Membrane Distillation Process. Journal of Membrane Science, 325, 383-394. http://dx.doi.org/10.1016/j.memsci.2008.08.001

[38] Xie, M., Nghiem, L.D., Price, W.E. and Elimelech, M. (2013) A Forward Osmosis-Membrane Distillation Hybrid Process for Direct Sewer Mining: System Performance and Limitations. Environmental Science and Technology, 47, 13486-13493. http://dx.doi.org/10.1021/es404056e

[39] Wang, K.Y., Teoh, M.M., Nugroho, A. and Chung T.-S. (2011) Integrated Forward Osmosis-Membrane Distillation (FO-MD) Hybrid System for the Concentration of Protein Solutions. Chemical Engineering Science, 66, 2421-2430. http://dx.doi.org/10.1016/j.ces.2011.03.001

[40] Ge, Q., Wang, P., Wan, C. and Chung, T.-S. (2012) Polyelectrolyte-Promoted Forward Osmosis-Membrane Distillation (FO-MD) Hybrid Process for Dye Wastewater Treatment. Environmental Science and Technology, 46, 6236-6243. http://dx.doi.org/10.1021/es300784h

[41] Husnain, T., Mi, B.X. and Riffat, R. (2015) A Combined Forward Osmosis and Membrane Distillation System for Sidestream Treatment. Journal of Water Resource and Protection, 7, 1111-1120. http://dx.doi.org/10.4236/jwarp.2015.714091

[42] Xie, M., Price, W. E., Nghiem, L. D. and Elimelech, M. (2013) Effects of Feed and Draw Solution Temperature and Transmembrane Temperature Difference on the Rejection of Trace Organic Contaminants by Forward Osmosis. Journal of Membrane Science, 438, 57-64. http://dx.doi.org/10.1016/j.memsci.2013.03.031

[43] Han, G., Zuo, J., Wana, C. and Chung, T (2015) Hybrid Pressure Retarded Osmosis - Membrane Distillation (PRO-MD) Process for Osmotic Power and Clean Water Generation. Water Resource Technology, 1, 507515. http://dx.doi.org/10.1039/c5ew00127g

[44] APHA (2012) Standard Methods for the Examination of Water and Wastewater, $22^{\text {nd }}$ Edition. American Public Health Association, Washington, D.C.

[45] Gray, J.R. (2004) Environmental Instrumentation and Analysis Handbook, Conductivity Analyzers and Their Application. $1^{\text {st }}$ Edition, Wiley-Interscience, New Jersey.

[46] Mi, B.X., Marinas, B.J. and Cahill, D.G. (2007) RBS Characterization of Arsenic(III) Partitioning fom Aqueous Phase into the Active Layers of Thin-Film Composite NF/RO Membranes, Environmental Science and Technology, 41, 3290-3295. http://dx.doi.org/10.1021/es062292v

[47] Metcalf and Eddy (2003) Wastewater Engineering: Treatment, Disposal and Reuse. $4^{\text {th }}$ Edition, McGrawHill, New York.

[48] Coronell, O., Mi, B.X.. Marinas, B.J. and Cahill, D.G. (2013) Modeling the Effect of Charge Density in the Active Layers of Reverse Osmosis and Nanofiltration Membranes on the Rejection of Arsenic(III) and Potassium Iodide. Environmental Science and Technology, 47, 420-428. http://dx.doi.org/10.1021/es302850p

[49] Qu, D., Wang, J., Hou, D., Luan, Z., Fan, B. and Zhao, C. (2009) Experimental Study of Arsenic Removal by Direct Contact Membrane Distillation. Journal of Hazardous Materials, 163, 874-879. http://dx.doi.org/10.1016/j.jhazmat.2008.07.042 